\title{
The Improvement of Learning Outcomes of Social Theme Using Group Investigation and Mind Mapping Models for Students in SDN 3 Alalak Selatan Banjarmasin
}

\author{
Raihanah Sari \\ Elementary School Teacher Education \\ Faculty of Teacher Training and Education \\ Universitas Lambung Mangkurat \\ Banjarmasin, Indonesia \\ reyhana89.rss@gmail.com
}

\begin{abstract}
Problem occurred on the theme of my living areas in IVA class on SDN 3 Alalak Selatan is some students tend to be inactive in learning. The causes of this problem are a teacher as centered on teaching. Learning is not practical and less fun, thus causing the number of students to score below KKM. The researcher chooses the model Group Investigation, and Mind Mapping for the sake of solving the problem. The researcher conducted Classroom Action Research in 2 Cycles with two meetings. Each cycle consists of 4 stages: planning, implementation, observation, and reflection. The subject of this research is the students of grade IV SDN Alalak Selatan 3 Kota Banjarmasin, which consist of 28 people. Data excavation using observation method in the form of student activity in learning and learning outcomes are excavated with end test of learning at the end of each lesson. The indicator of success for students is considered complete learning if the acquisition of a classical value of $80 \%$ of the total students got a score of $\geq 80$. Based on the research results can be seen that the application of collaboration model Group Investigation, and Mind Mapping, that for liveliness learning students obtain very active criteria. While for the results, the students get the criteria for complete individual and classical.
\end{abstract}

Keywords - Learning Outcomes, Group Investigation, Mind Mapping.

\section{INTRODUCTION}

There are many kinds of educations in Indonesia and is one of the most important things in every individual. Education is a fundamental problem for every country including Indonesia, which is a developing country. Therefore, education here greatly influences human development in all aspects of life and personality. Education is the first stage of learning in realizing a quality and character education. Reference [1] states that education is "conscious and planned effort to realize the learning atmosphere and learning process so that students actively develop their potential to have spiritual strength, self-control, personality, intelligence, noble character, and the skills needed by themselves, community, nation, and state." This education is as an activity that cannot be separated from its function and purpose. The achievement of an educational goal as desired by the government in the implementation of this education, here the teacher also participates in the implementation of education. Where a teacher is a primary facilitator in a school that functions to explore, develops, and optimizes the potential possessed by students so that they can become part of a civilized society. Where the primary task of a teacher is to plan to learn, carry out learning and also assess the learning outcomes of students [2].

The teaching process that is more lively and collaborative among students is the hope of each learning process. The learning process with the old paradigm must be changed with a new standard that can increase students' creativity in thinking, the direction of learning is more involved not only one directed so that the teaching and learning process will be able to reach collaboration between students and teachers and students with students, thus students who less than others will be assisted by smarter students so that the learning process is alive and the results are better.

Efforts to achieve optimal learning outcomes can be seen from the success of students in understanding a subject matter. The subject matter that is in the Elementary School education unit is the primary learning material that is by the characteristics of student development.

The 2013 curriculum applied based on competency was designed to anticipate skills in the modern era. The 2013 curriculum adheres to: (1) learning conducted by the teacher (taught curriculum) in the form of the process that is developed in the way of learning activities in school, class, and society; and (2) the learning experience directly learned (learned curriculum) in accordance with background, characteristics, and ability to be educated. The 2013 curriculum aims to prepare Indonesian people to have the ability to live as individuals and citizens who are faithful, productive, creative, innovative, and useful, as well as able to 
contribute to the lives of society, nation, state and civilization, the world [3].

The 2013 curriculum is not a new curriculum in the world; curriculum like this has been applied in Finland, Germany, and France. The 2013 curriculum form at the primary education level uses an integrated thematic system by emphasizing the scientific approach in the teaching and learning process. Integrative thematic learning is a learning approach that integrates various competencies from various subjects into different themes [4].

Learning in elementary schools as in the 2013 curriculum covers a variety of subjects. One of them is the content of Social Sciences (IPS) which is the subject or the main content in elementary school. At the primary school level, Social Sciences are a combination of historical items, geography, and economics [5].

Social Sciences subjects are specifically designed to develop knowledge and understanding of the social conditions of society, in entering the social life of students also required to be able to instill the attitude of the nation amid the influence of the era of globalization. Social Sciences is one of the subjects in schools that plays an essential role in developing human resources in shaping quality students and becoming good citizens. The students grow and develop as part of the community, and students are faced with various problems that exist and occur in the environment [6].

In elementary school, especially for schools that use the 2013 Curriculum, learning is needed that can lead students towards a level of understanding social knowledge which later becomes a provision for students in dealing with the state of their social environment. With this basis, the learning of social science at the elementary school level requires a learning model that can increase students' social activities. Related to the teacher's role and enthusiasm of students towards social studies learning for elementary school students, there are still many problems in learning. Based on the opinion in reference [7] about children indicator motivation stated that people who have motivation are as follows: (1) Doing things as well as possible; (2) Do something by achieving success; (3) Complete tasks that require effort and skill; (4) Desiring to become a famous person and master specific fields; (5) Doing difficult things with satisfying results; (6) Doing something significant; (7) Do something better than others.

The causes that cause problems that are still found in Alalak Selatan 3 Elementary School, Banjarmasin city, namely the success of teachers in carrying out learning activities are influenced by the success of the teacher in delivering the material and understood by students. If the lessons are provided well, then it allows the teacher and students to be able to teach and learn well. The problem that still arises today is that teachers still lack the application of innovative models to support learning to be more meaningful. Especially in the 2013 Curriculum for $1 \mathrm{x}$ meetings or $1 \mathrm{x}$ learning contains several subjects. Not all teachers can deliver the material appropriately and adequately; this is because the skill level of each teacher is different. For teachers who can make variations of teaching well, the teacher can deliver the material optimally by the needs of students.
The teacher's style of teaching in the learning process generally uses lectures and students are required to listen to lectures from the teacher. The teacher uses most of his time to convey information to students. The teacher seems to be the main one in the learning process and often does not involve student activity during the learning process. The use of lecture methods that are applied purely will not be able to engage students actively in the teaching and learning process. When observed, the teacher places more on the intellectual abilities of each student's achievement of values and less focus on other aspects. School is one of the competition arenas. Starting from the beginning of the formal education period a child learns in an atmosphere of competition and must fight hard to win the game to be able to go up the class or graduate. Competition is not the only learning model that can and should be used [8]. Many other models can be used by teachers to involve student learning activities.

Other causes that are still found in Alalak Selatan 3 Elementary School are the 2013 Curriculum learning which is only fixated on learning support textbooks without regard to the learning process. The teacher is always pursuing the material to quickly spend subtitles after sub-themes to catch up with the time to fulfill the time provided for UAS preparation so that in this case it makes students tend to be inactive due to teacher-centered learning. Students who are not active in learning are also due to those who still have each ego in their learning activities. So that students cannot focus their attention and seriousness in learning.

Based on the data obtained from the fourth-grade teachers of Alalak Selatan 3 Elementary School in Banjarmasin City on 9 January 2018, as many as $55.56 \%$ of students from 28 students whose first-semester test scores on social studies have not yet reached the KKM, which is 70. Low-grade student learning outcomes IV in the Social Sciences lesson at Alalak Selatan 3 Elementary School, Banjarmasin City, can be seen from the average score of five fields of study.

Based on the description above, it encourages the writer to research improving learning outcomes in the theme of my place of residence with the contents of social studies using Group Investigation learning model with Mind Mapping model for fourth-grade students of Alalak Selatan 3 Elementary School in Banjarmasin City. Design a problemsolving plan through an action improvement learning process using two cycles in classroom action research using Group Investigation learning models and Mind Mapping models.

Model Group Investigation is often referred to as the most complex cooperative learning method. This is due to this method combining several rationales, which is based on constructivist views, democratic teaching, and cooperative learning groups.

Based on constructivist views, the Group Investigation (GI) learning model can be used by teachers to develop creativity in thinking of students, both regarding groups and groups. The model of the Investigation Group is designed to help students share their responsibilities following learning and orientation to form social enthusiasm [9]. 
Group investigation is the most complex and most difficult to implement cooperative learning model [6]. Thelan first developed this model. In its development, this model was expanded and sharpened by Sharan from Tel Aviv University. Unlike STAD and jigsaw, students are involved in planning both the topics being studied and how their investigations are conducted. This learning requires class norms and structures that are more complicated than a more teacher-centered approach. This approach also requires teaching students in good communication and group process skills.

Whereas reference [10] states that, Mind mapping, this is the easiest to incorporate information into the box and to return to taking data from the box. Mind Mapping is the best technique in helping the process of thinking about the rules because they use techniques that are based on human thinking that are useful for providing universal keys so that they can develop potential [10].

\section{METHOD}

This study is using a qualitative approach. A qualitative approach is a research aimed at describing and analyzing phenomena, events, social activities, attitudes, beliefs, perceptions, thoughts of individuals individually or in groups [11].

Qualitative research researches a small scale, groups that have specificity, excellence, innovation or are also problematic. The group under study is a socio-cultural unit that interacts individually or in groups. Sometimes the groups studied are subgroups that have abnormalities or differences with large groups, slow classes, subjects that students do not like or low learning achievement [11].

The type of research used is According to reference [12]; CAR (classroom action research) consists of three words, namely research, action, and classroom. First is research. Research is defined as the act of observing an object by using specific methods and rules or methodologies to find accurate data about things that can improve the quality of the object being observed. Second is action. The action is a deliberate and planned movement with a specific purpose. The third is the class. The class is a place where there is a group of students who at the same time receive lessons from the same teacher.

Of the three elements mentions above, it can be concluded that what is meant by CAR is an observation in the form of actions towards learning activities that are intentionally raised and occur in a class simultaneously. According to reference [13], there are four stages in the action research model, namely: planning, implementing, observing, and reflecting. The four steps of the research will form a cycle, which is one round of activities in sequence and will be returned to the next period as before. So, one period is from the stage of preparation to reflection, and reflection here is an evaluation material for the actions that the teacher must do next.

This classroom action research activity was carried out on the theme of my place of residence with social studies in class IV A SD Alalak Selatan Banjarmasin city, odd semester,
2018/2019 school year with the number of 28 students consisting of 8 male students and 20 female students.

Researchers chose SD-Alalak Selatan 3 Banjarmasin City to be used as a place of research because it was based on an interview on 23 November 2017 with the class IV guardian, Ibu Maymunah, S.Pd who stated that the implementation of learning with the 2013 curriculum had not run optimally with indicators of success that were only at pretty good category. In addition, based on observations of research activities of students in the learning process is still not optimal because of the lack of enthusiasm of most students to be actively involved in following the learning process, some of the active students do have a high interest in the learning process, they have their initiative in determining solution in every problem that exists in learning activities. However, based on his narrative, the teacher still feels not yet proficient and so masters in the application of the 2013 Curriculum, so that the potential development of students who have more and creative abilities in solving problems has not received much attention, and for this reason, research is needed to overcome these weaknesses.

\section{RESULTS AND DISCUSSION}

Based on the results of the research, it obtained by researchers working on some activities during the learning process conducted research activities took place when the implementation of social studies learning used Group Investigation learning a model with Mind Mapping model for fourth-grade students of SDN Alalak Selatan 3 Banjarmasin in East Timor. The cognitive aspects of the first cycle of meeting 1 put $68.9 \%$ of students in the complete category; this result then increased to 2 in the meeting to $72.4 \%$ for students who got the complete category. In the second cycle of meeting 1 , the cognitive value of students who were in the complete category again increased to $89.6 \%$, and at meeting 2 , it increased to $100 \%$ or all students got a complete category.

In the affective aspect in the first cycle of meeting 1 there were only $60.7 \%$ of students who obtained the category of being civilized for all the accumulated attitudes that were determined using a score range between $3.01-4.00$ on a scale of 1-4 or a value between 76-100 in scale of 100 in the 2013 curriculum assessment provisions. These results also increased drastically as in the cognitive aspect in the second cycle of meeting two which put $71.4 \%$ of students in the category of Cultivation. The results again showed an increase in the second cycle of meeting one which placed $89.2 \%$ of students in the already entrenched category. Then it can be refined in cycle 2 of meeting two that is $100 \%$ of students have obtained the category of being entrenched.

Similar results were also shown by the psychomotor aspects which in the first cycle of meeting 1 placed $75.8 \%$ of students in the complete category. This result increased dramatically in the second cycle of meeting two which placed $100 \%$ of students in the complete category. The results that have been recovered are increased in the second cycle of meeting 1 which places $100 \%$ of students in the complete category. In the second cycle of meeting 2 can still be maintained perfectly $100 \%$ of students get the complete category. 
Student learning outcomes are also measured using a final cycle test. The final test of this cycle uses an essay question instrument with a question component covering material taught in 2 meetings in each cycle. The final cycle I test results obtained by students were $75 \%$ or 21 students were in the complete category. This result does not meet the success indicators set by the teacher, but in the final test of cycle II, this result increases until all students or $100 \%$ of the total students get the complete category.

\section{CONCLUSION}

Based on the results of research carried out in SDN-Alalak Selatan 3, Banjarmasin City on learning with the theme of the area of my place of residence, it can be concluded as follows:

- Students' activities when implementing learning using a combination of GI learning models with Mind Mapping, in the theme area of learning I live with the contents of IPS has increased and achieved very active criteria.

- The use of a combination of GI learning model with Mind Mapping, in the learning of the theme of the Area of My Excellency with the contents of IPS in grade IVA students of SDN-Alalak Selatan 3 in Banjarmasin City achieved the completeness of learning outcomes that were above the completeness value standard which is more than $>80 \%$.

\section{REFERENCES}

[1] R. Indonesia, Undang-Undang Republik Indonesia Nomor 20 Tahun 2003 tentang Sistem Pendidikan Nasional, Jakarta: Sekretariat Negara, 2003.

[2] E. Karwati and D. J. Priansa, Manajemen kelas. Bandung: Alfabeta, 2014.

[3] R. Indonesia, Permendikbud No. 67 of 2013 tentang kurikulum SD/MI. Jakarta: Sekretariat Negara, 2013.

[4] H. Husamah and Y. Setyaningrum, Desain pembelajaran berbasis pencapaian kompetensi. Jakarta: Prestasi Pustakakarya, 2013.

[5] A. Hidayati, M. Zaim, K. Rukun, and D. Darmansyah, "The development of character education curriculum for elementary student in West Sumatera Padang state university," International Journal of Education and Research. vol. 2, no. 6, 2014.

[6] T. Trianto, Panduan pelaksanaan penelitian tindakan kelas. Jakarta: Prestasi Pustakarya, 2011.

[7] A. P. Mangkunegara, Sumber daya manusia perusahaan. Bandung: Remaja Rosdakarya, 2005.

[8] A. Lie. Cooperative Learning mempraktikkan cooperative learning di ruang-ruang kelas. jakarta: Grasindo, 2010.

[9] R. Rusman, Model-model pembelajaran. Jakarta: PT. Raja Grasindo Persada, 2012.

[10] B. Bary, and Tony, Memahami peta pikiran: The Mind Map Book. Batam: Interaksa, 2004

[11] N. S. Sukmadinata, Metode penelitian pendidikan. Bandung: PT Remaja Rosdakarya, 2013.

[12] S. Arikunto, Prosedur penelitian. Jakarta: PT Rineka Cipta, 2010 